\title{
Titanium dioxide nanowires modified tin oxide hollow spheres for dye-sensitized solar cells
}

\begin{abstract}
Yajie Wang, Chengbin Fei, Rong Zhang, and Lixue Guo, Beijing Institute of Nanoenergy and Nanosystems, Chinese Academy of Sciences , Beijing 100083, China; National Center for Nanoscience and Technology (NCNST), Beijing 100083, China

Ting Shen, and Jianjun Tian, Advanced Material and Technology Institute, University of Science and Technology, Beijing 100083, China

Guozhong Cao, Beijing Institute of Nanoenergy and Nanosystems, Chinese Academy of Sciences, Beijing 100083, China; National Center for Nanoscience and Technology (NCNST), Beijing 100083, China; Department of Materials and Engineering, University of Washington, Seattle, WA 98195-2120, USA

Address all correspondence to Guozhong Cao at gzcao@u.washington.edu and Jianjun Tian at tianjianjun@mater.ustb.edu.cn
\end{abstract}

(Received 24 June 2016; accepted 22 August 2016)

\begin{abstract}
Tin oxide $\left(\mathrm{SnO}_{2}\right)$ hollow spheres modified with titanium dioxide $\left(\mathrm{TiO}_{2}\right)$ nanowires (NWs) synthesized by sequential hydrothermal reactions were investigated as photoanodes for dye-sensitized solar cells. Not only does the hydrothermal treatment form numerous short $\mathrm{TiO}_{2}$ NWs on the surface of $\mathrm{SnO}_{2}$ spheres, but also passivates the surface of $\mathrm{SnO}_{2}$. Consequently, the specific surface area of the photoanode and dye loading are almost doubled, at the same time the surface defects and charge recombination are both appreciably reduced. As a result, the short-circuit photocurrent density and open-circuit photovoltage both greatly increased. The power conversion efficiency of the solar cells increases from $0.4 \%$ to $2.9 \%$.
\end{abstract}

\section{Introduction}

Since titanium dioxide $\left(\mathrm{TiO}_{2}\right)$ nanoparticles first has been combined with dye molecules to fabricate low-cost photovoltaic device in 1991, dye-sensitized solar cells (DSCs) have attracted extensive interest in the past few decades as a promising candidate to convert solar energy to electricity. ${ }^{[1-3]}$ Although using $\mathrm{TiO}_{2}$ nanoparticle films with collaborated silyl-anchor and carboxy-anchor dyes has achieved a power conversion efficiency of higher than $14 \%$ in $2015,{ }^{[4]} \mathrm{TiO}_{2}$ as photoanodes in DSCs still face many challenges. ${ }^{[5,6]}$ It has become a focus recently that looking for alternative metal oxide semiconductors with wide band gap and good photoelectrochemical properties. ${ }^{[7-10]}$ $\mathrm{ZnO}$ nanostructures for DSC applications has shown that they can offer large specific surface areas with well-controlled morphologies, direct electron pathways with much higher electron mobility, and also can reduce the combination rate when the surface defects are properly controlled. ${ }^{[1-13]}$ Tin oxide $\left(\mathrm{SnO}_{2}\right)$ as a promising alternative semiconductor has many advantages for DSCs: (1) good electron mobility, indicating electron transport fast in photoanodes and (2) large band gap (3.6 $\mathrm{eV}$ ) and more-negative conduction band minimum, which can enhance the light harvesting in the near-infrared spectral region when combined with small band gap sensitizer. ${ }^{[14]}$

Many different nanostructures of $\mathrm{SnO}_{2}$ have been synthesized with a variety of methods with emphasis to avoid its weakness, such as electron recombination and surface defects. ${ }^{[15]}$ Low-dimensional nanostructures of $\mathrm{SnO}_{2}$ have been widely reported, including zero-dimensional (0D) nanoparticles, ${ }^{[16]}$ one-dimensional (1D) nanorods, ${ }^{[17]}$ nanobelts, ${ }^{[18]}$ nanotube, ${ }^{[19]}$ and nanowires (NWs). ${ }^{[0]}$ The process of $\mathrm{SnO}_{2}$ nanostructure synthesis is always related to chemical reaction of tin precursor and crystallization of $\mathrm{SnO}_{2}$. Different reaction parameters, such as the concentration of precursor solution, $\mathrm{pH}$ value and addition agent, will influence the morphology of $\mathrm{SnO}_{2}$ nanostructure eventually. In addition, in order to solve the problem that less dye adsorption of $\mathrm{SnO}_{2}$ owing to lower isoelectric point (i.e.p., at $\mathrm{pH} 4-5$ ), coating other metal oxide such as $\mathrm{TiO}_{2}$ (i.e.p., at $\left.\mathrm{pH} 6-7\right)^{[21]}$ can increase the cell efficiency of DSCs. ${ }^{[22,23]}$ For example, in $2011 \mathrm{Wu}$ et al. ${ }^{[24]}$ synthesized hierarchical structure consisting of $2 \mathrm{D} \mathrm{SnO}_{2}$ nanosheets and other metal oxides to increase the open-circuit photovoltage. Among the large number of materials, $1 \mathrm{D} \mathrm{TiO} 2 \mathrm{NWs}$ with superior light-scatting ability can provide a direct way to transport electrons and enhance the performance of the whole solar cells. ${ }^{[25-29]}$ In addition, $\mathrm{TiO}_{2}$ NWs can also provide a rapid electron transfer and reduce the electron recombination rate. As a result, the power conversion efficiency is greatly improved. ${ }^{[30]}$

In this paper, $\mathrm{SnO}_{2}$ hollow spheres (HSs) made of $\mathrm{SnO}_{2}$ nanoparticles modified with $\mathrm{TiO}_{2} \mathrm{NWs}$ were employed as photoanodes for DSCs. The uniform $\mathrm{SnO}_{2}$ spheres are synthesized without using any template through a hydrothermal method, which makes the reaction product with better crystallinity and less surface defects. When such $\mathrm{SnO}_{2} \mathrm{HSs}$ were modified with $\mathrm{TiO}_{2} \mathrm{NWs}$, the large specific surface area, less surface defect, and good light-scatting properties make it an attractive 
alternative photoanode materials with high dye loading, effective light absorption, direct electron transport path, and reduced charge recombination. The short-circuit photocurrent density and open-circuit photovoltage both have been greatly increased. The power conversion efficiency of the solar cell based on $\mathrm{SnO}_{2}$ HSs coated with $3 \mathrm{D} \mathrm{TiO}_{2} \mathrm{NWs}$ as photoanodes reached $2.9 \%$, which presents six times of enhancement as compared with the DSCs with $\mathrm{SnO}_{2}$ HS anodes.

\section{Experimental methods Synthesis of $\mathrm{SnO}_{2} \mathrm{HSs}$}

The $10 \mathrm{mmol}$ of $\mathrm{SnCl}_{2}$ (1 $\mathrm{M}$ in concentration) were dissolved in $10 \mathrm{~mL}$ mixture of ethanol and hydrochloric acid (9:1 in volume) and stirred for $5 \mathrm{~min}$. The solution was transferred to a 35 $\mathrm{mL}$ reaction tube and reactor cavity of the CEM Discover microwave system. The synthesis parameters were set as: $T=$ $180^{\circ} \mathrm{C}$, dwell time $=2 \mathrm{~h}$, power $=120 \mathrm{w}$, and pressure $=17$ bars. After cooling naturally, the precipitate was harvested by centrifugation at $8000 \mathrm{rpm}$ for $30 \mathrm{~min}$ and washed thoroughly with deionized (DI) water for at least three times. The brown powder was calcined at $450{ }^{\circ} \mathrm{C}$ for $3 \mathrm{~h}$ to remove the inner carbon sphere completely to obtain $\mathrm{SnO}_{2}$ HSs.

\section{Preparation of $\mathrm{SnO}_{2}$ paste}

$\mathrm{SnO}_{2}$ powders $(0.18 \mathrm{~g})$ were placed in an agate mortar, and $5.0 \mathrm{~mL}$ of ethanol was added dropwise into the mortar. The $\mathrm{SnO}_{2}$ powders were ground for $30 \mathrm{~min}$. The ground $\mathrm{SnO}_{2}$ was then transferred to a solution of terpineol $(0.73 \mathrm{~g})$ and ethyl cellulose $(0.09 \mathrm{~g})$ in a $10 \mathrm{~mL}$ beaker under magnetic stirring. The dispersion was homogenized by means of ultrasonic and magnetic stirring overnight. A layer of $\mathrm{SnO}_{2}$ film was prepared by the doctor blade technique. The film was sintered at $500{ }^{\circ} \mathrm{C}$ for $60 \mathrm{~min}$ in air to remove any organic compounds.

\section{Synthesis of $\mathrm{SnO}_{2} \mathrm{HSs}$ coated with $\mathrm{TiO}_{2} \mathrm{NWs}$} $\mathrm{K}_{2} \mathrm{TiO}\left(\mathrm{C}_{2} \mathrm{O}_{4}\right)_{2}(0.35 \mathrm{~g})$ was added to the mixture solvent containing diethylene glycol (DEG) and DI water in different volume ratios $(0: 20,1: 19,10: 10,19: 1)$, while the total volume of the solution was $20 \mathrm{~mL}$. The solution was transferred to a $50 \mathrm{~mL}$ Teflon-lined stainless steel autoclave. Then as-prepared $\mathrm{SnO}_{2}$ films were placed at an angle against the wall of the
Teflon-liner with the film side facing down. The hydrothermal synthesis was carried out by putting the autoclave in an oven at $180{ }^{\circ} \mathrm{C}$ for $6 \mathrm{~h}$ with a heating rate of $5^{\circ} \mathrm{C} / \mathrm{min}$ and air-cooled to room temperature naturally. Subsequently, the samples were rinsed with DI water, ethanol, and sintered at $500{ }^{\circ} \mathrm{C}$ for 60 min in air to increase crystallinity.

\section{Fabrication of DSCs}

The electrodes with a cell area of $0.25 \mathrm{~cm}^{2}$ were immersed in a $0.25 \mathrm{mM}$ N719 sensitizer dye for $18 \mathrm{~h}$. The counter-electrodes were Pt-coated fluorine doped tin oxide (FTO), and the electrolyte was contained $I^{-} / I^{3-}$ redox. The DSCs with $\mathrm{TiO}_{2} \mathrm{NWs}$ treatment (DEG: $\mathrm{DI}=1: 19$ ) and without $\mathrm{TiO}_{2} \mathrm{NWs}$ treatment were designed by $\mathrm{SnO}_{2} \mathrm{HS}-\mathrm{TiO}_{2} \mathrm{NW}$ and $\mathrm{SnO}_{2} \mathrm{HS}$.

\section{Characterization}

X-ray diffraction (XRD) measurements were conducted on an X'Pert PROS (Philips Co.) with a radiation of $\mathrm{Cu} \mathrm{K} \mathrm{K}_{\alpha}(\lambda=$ $1.54060 \AA$ ). Hitachi SU8020 scanning electron microscope (SEM) system was employed to analyze the morphology. The absorption spectra were measured using a Shimadzu UV3600 spectrophotometer. $\mathrm{N}_{2}$ adsorption-desorption isotherms were recorded on ASAP2020 instrument (Micromeritics Co.), and the specific surface areas [Brunauer-Emmett-Teller (BER)] were calculated using the BET equation. Desorption isotherm was used to determine the pore-size distribution using the Barret-Joyner-Halender (BJH) method. The photovoltaic characteristics of the solar cells were evaluated using simulated AM 1.5 sunlight with an output power of $100 \mathrm{~mW} /$ $\mathrm{cm}^{2}$. The incident monochromatic photon-to-electron conversion efficiency (IPCE) plotted as a function of excitation wavelength were recorded IM6ex (Zahner, Germany) using light-emitting diodes (LED; $\lambda=455 \mathrm{~nm}$ ) driven by Expot (Zahner, Germany). The electrochemical impedance spectroscopy (EIS) data were fit to the equivalent circuits by using Zview software (Scribner Associates). Impedance measurements were carried out under illumination from LED.

\section{Results and discussion}

Scheme 1 is the proposed schematic illustrating the formation process of the $\mathrm{SnO}_{2} \mathrm{HSs}$ and subsequent modification with

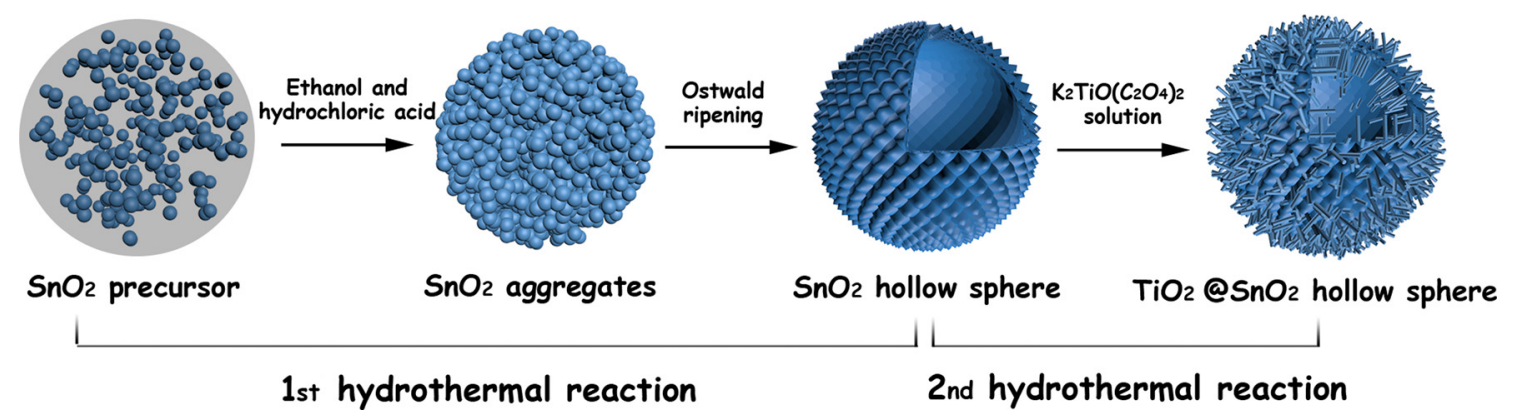

Scheme 1. The schematic of the formation processes for the $\mathrm{SnO}_{2} \mathrm{HSs}$ and the subsequent growth of $\mathrm{TiO}_{2} \mathrm{NWs}$ on the surface of $\mathrm{SnO}_{2} \mathrm{HSs}$. 


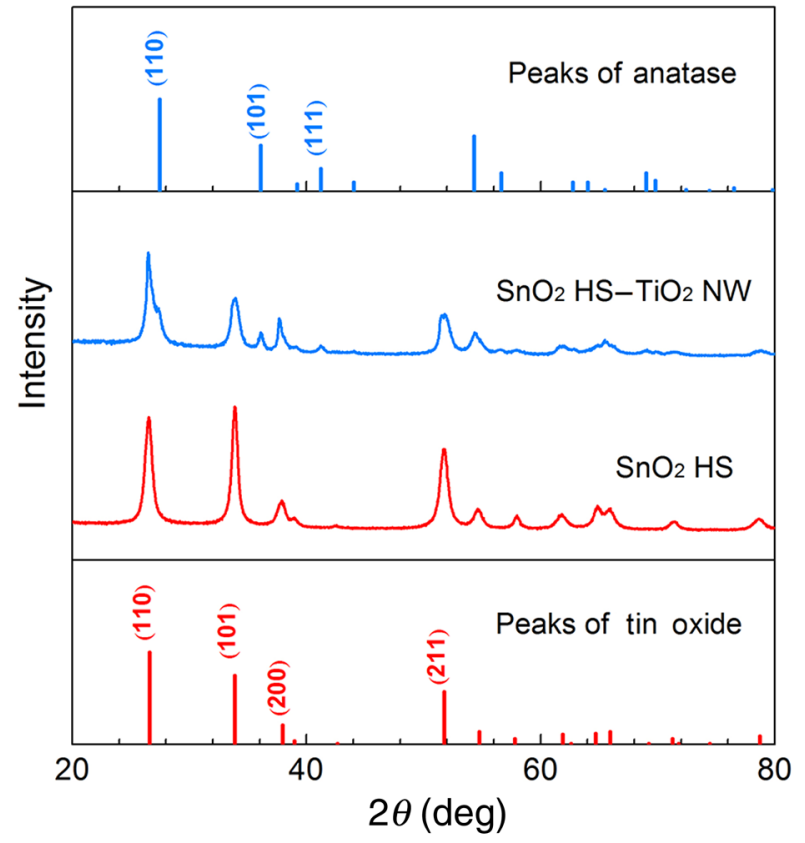

Figure 1. XRD patterns of $\mathrm{SnO}_{2} \mathrm{HS}$ and $\mathrm{SnO}_{2} \mathrm{HS}-\mathrm{TiO}_{2} \mathrm{NW}$ powders showing $\mathrm{SnO}_{2} \mathrm{HSs}$ having a rutile crystal structure while $\mathrm{TiO}_{2} \mathrm{NWs}$ with an anatase crystal structure.
$\mathrm{TiO}_{2} \mathrm{NWs}$. The formation of $\mathrm{SnO}_{2} \mathrm{HSs}$ without using templates could be ascribed to a simple Ostwald ripening process as reported in literature. ${ }^{[31]}$ The solid spherical aggregates were first formed by the self-assembly of $\mathrm{SnO}_{2}$ nuclei through the oxidation and hydrolysis reactions of $\mathrm{Sn}^{2+}$. Since the particles that located in the inner cores have poor crystallinity as well as higher surface energies, they are more easily dissolved at high temperatures (fast kinetics in hydrothermal growth condition). With reaction proceeds, the interior cavities will be generated within the solid spheres, and hollow $\mathrm{SnO}_{2}$ spheres can be obtained. Besides, the as-prepared thorn-like nanoparticles around the HSs probably can be explained by the acid etching effect of hydrochloric acid. The uniformly sized $\mathrm{SnO}_{2} \mathrm{HSs}$ of approximately $200 \mathrm{~nm}$ in diameter are composed of $15 \mathrm{~nm}$ nanoparticles, then blade coating on the FTO. The $\mathrm{SnO}_{2}$ films are coated with $\mathrm{TiO}_{2}$ NWs using the hydrothermal synthesis in the Teflon-liner stainless steel autoclave. In order to fabricate $\mathrm{TiO}_{2} \mathrm{NWs}$, the $\mathrm{SnO}_{2}$ films immersed in a solution with titanium potassium oxalate and a mixture solvent containing DEG and DI water. In reaction process, DEG plays a role as capping agent to control morphology of $\mathrm{TiO}_{2}$ nanostructure by means of changing volume ratios of DEG and DI water. ${ }^{[32,33]}$ The advantage of this hierarchical nanostructure lies in HSs provided with the large specific surface area and enhanced light scatting, at the same time $\mathrm{TiO}_{2} \mathrm{NWs}$ can provide a direct transport path for electrons transport. In addition, (a)

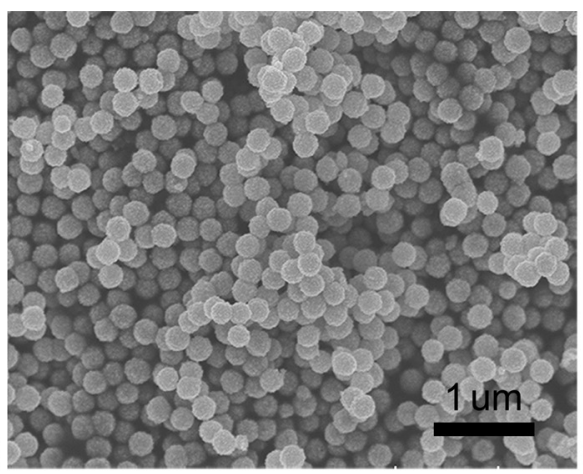

(b)
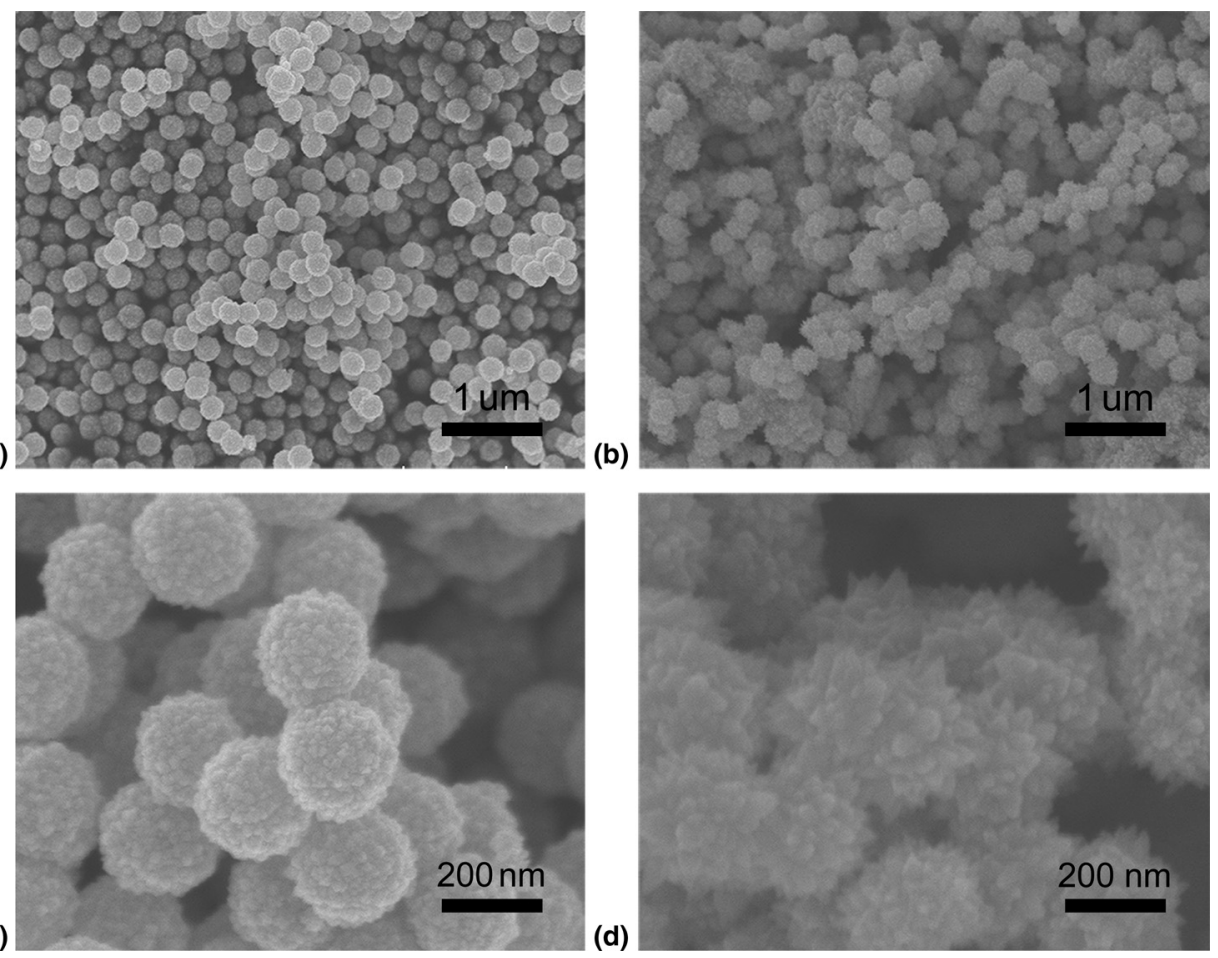
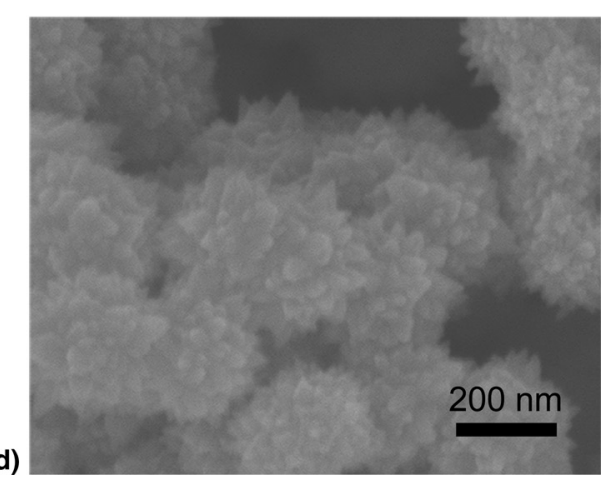

Figure 2. SEM images of: (a, c) $\mathrm{SnO}_{2} \mathrm{HS}$ nanostructure, (b, d) $\mathrm{SnO}_{2} \mathrm{HS}$ with $\mathrm{TiO}_{2} \mathrm{NWs}$ structure. 

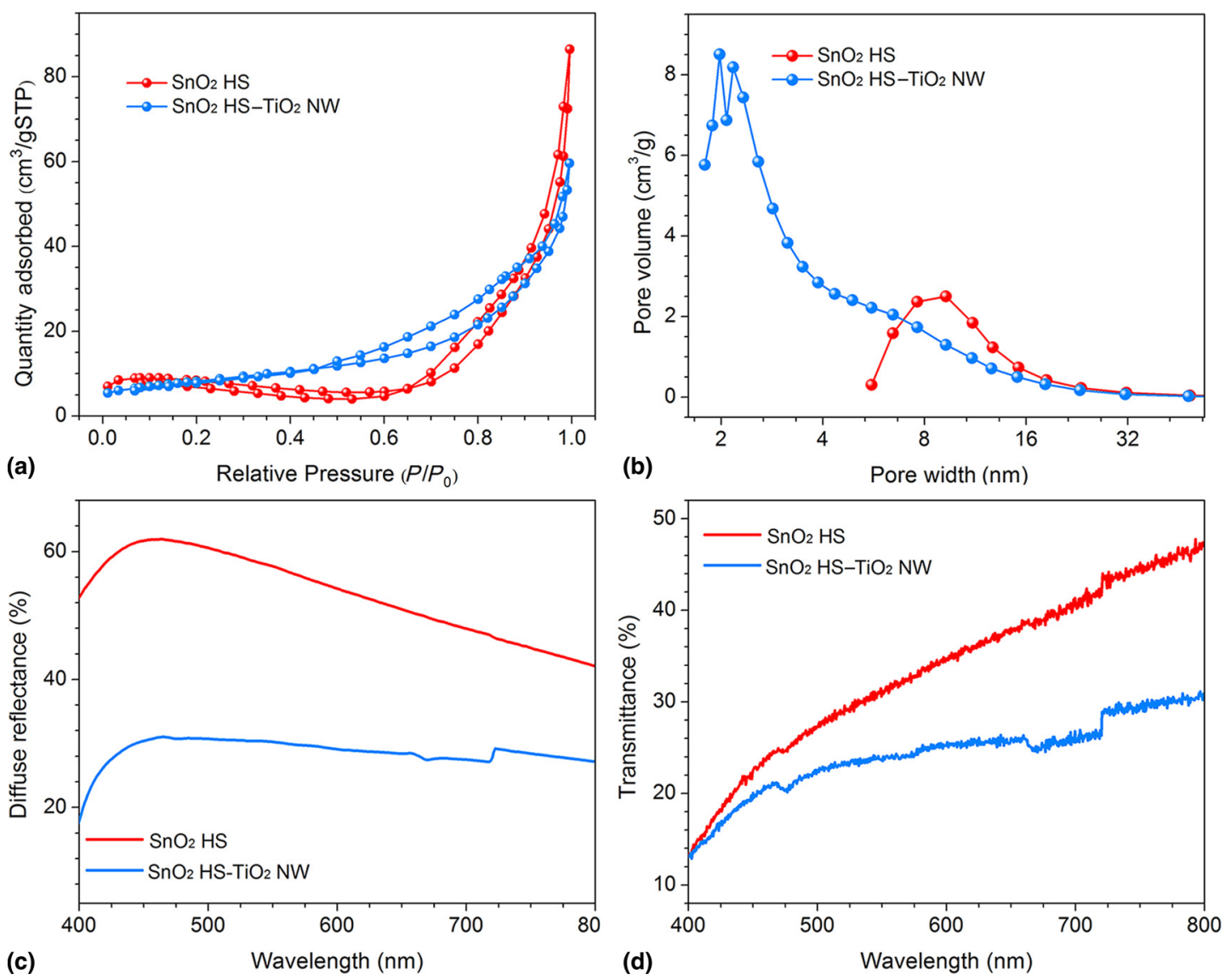

Figure 3. (a) Nitrogen adsorption and desorption isotherms at $77 \mathrm{~K}$, and (b) the pore-size distribution of $\mathrm{SnO}_{2} \mathrm{HS}_{\text {and }} \mathrm{SnO}_{2} \mathrm{HS}^{-\mathrm{TiO}_{2}} \mathrm{NW}_{\text {powders. }}$ (c) The diffuse reflectance curves and (d) transmission spectra of $\mathrm{SnO}_{2} \mathrm{HS}$ and $\mathrm{SnO}_{2} \mathrm{HS}-\mathrm{TiO}_{2} \mathrm{NW}$ photoanodes without dye loading.

the surface of $\mathrm{SnO}_{2} \mathrm{HS}$ is also passivated by $\mathrm{TiO}_{2}$ to reduce the surface defects.

To clearly show the composition changes in the materials, we measured the $\mathrm{SnO}_{2} \mathrm{HSs}$, and $\mathrm{SnO}_{2} \mathrm{HSs}$ modified with $\mathrm{TiO}_{2}$ samples with an x-ray diffractomer. As shown in Fig. 1, the XRD patterns of $\mathrm{SnO}_{2} \mathrm{HS}$ and $\mathrm{SnO}_{2} \mathrm{HS}-\mathrm{TiO}_{2} \mathrm{NW}$ have undergone significant changes. $\mathrm{SnO}_{2} \mathrm{HS}$ powder has the tetragonal rutile structure with lattice constants of $a=4.738$ and $c=$ $3.187 \AA$, while $\mathrm{SnO}_{2} \mathrm{HS}-\mathrm{TiO}_{2} \mathrm{NW}$ powder has the $\mathrm{TiO}_{2}$ anatase structure with lattice constants of $a=4.593$ and $c=2.959$ $\AA$. No other impurity crystal is detectable, which suggests that template-free growth can effectively form high-purity tetragonal rutile $\mathrm{SnO}_{2}$ crystal and the subsequent hydrothermal growth results in the growth of anatase $\mathrm{TiO}_{2}$ NWs.

Figures 2(a) and 2(c) are the different magnification SEM images of $\mathrm{SnO}_{2}$ HSs. The template-free hydrothermal method can form $\mathrm{SnO}_{2} \mathrm{HSs}$ with almost identical appearance. A close look reveals that the $\mathrm{SnO}_{2}$ HSs of $200 \mathrm{~nm}$ in diameter are the assembly of nanoparticles of $15 \mathrm{~nm}$ in diameter. Figures 2(b) and 2(d) show the different magnification SEM images of $\mathrm{SnO}_{2} \mathrm{HS}-\mathrm{TiO}_{2} \mathrm{NW}$ structure. When titanium potassium oxalate exists in the mixture solvent containing DEG and DI water under sufficiently high temperature and long duration, it can form a globular structure consisting of $\mathrm{TiO}_{2} \mathrm{NWs}$. It can also form $\mathrm{TiO}_{2} \mathrm{NWs}$ on the surface of $\mathrm{SnO}_{2} \mathrm{HSs}$ because of increasing active growth sites. Adjusting DEG and DI water volume ratios to $1: 19, \mathrm{TiO}_{2} \mathrm{NWs}$ grow with a diameter of 30 $50 \mathrm{~nm}$.

The $\mathrm{SnO}_{2} \mathrm{HS}$ and $\mathrm{SnO}_{2} \mathrm{HS}-\mathrm{TiO}_{2} \mathrm{NW}$ powders were further characterized by means of nitrogen sorption isotherms at $77 \mathrm{~K}$ as shown in Fig. 3(a), and the corresponding pore-size distribution is presented in Fig. 3(b). It is found that the $\mathrm{SnO}_{2} \mathrm{HSs}$ have a very low BET surface area, only $20.8 \mathrm{~m}^{2} / \mathrm{g}$ with an average BJH pore diameter of $17.3 \mathrm{~nm}$ and a pore volume of $0.15 \mathrm{~cm}^{3} / \mathrm{g}$. By contrast, the $\mathrm{SnO}_{2} \mathrm{HS}-\mathrm{TiO}_{2} \mathrm{NWs}$ have $39.3 \mathrm{~m}^{2} / \mathrm{g}$ BET surface area with BJH pore diameter $10.5 \mathrm{~nm}$ and $0.09 \mathrm{~cm}^{3} / \mathrm{g}$ pore volume. Although it might look against the intuition, $\mathrm{SnO}_{2} \mathrm{HS}$ sample with relatively low pore volume and low BET surface area is reasonable. The nitrogen sorption isotherms through surface adsorption and capillary condensation are valid in the microporous and mesoporous regions. When the voids inside the $\mathrm{SnO}_{2} \mathrm{HSs}$ are larger than $100 \mathrm{~nm}$, isotherms can have significant deviation. The isotherm for $\mathrm{SnO}_{2}$ HSs in Fig. 3(a) demonstrated a substantial reduction in 

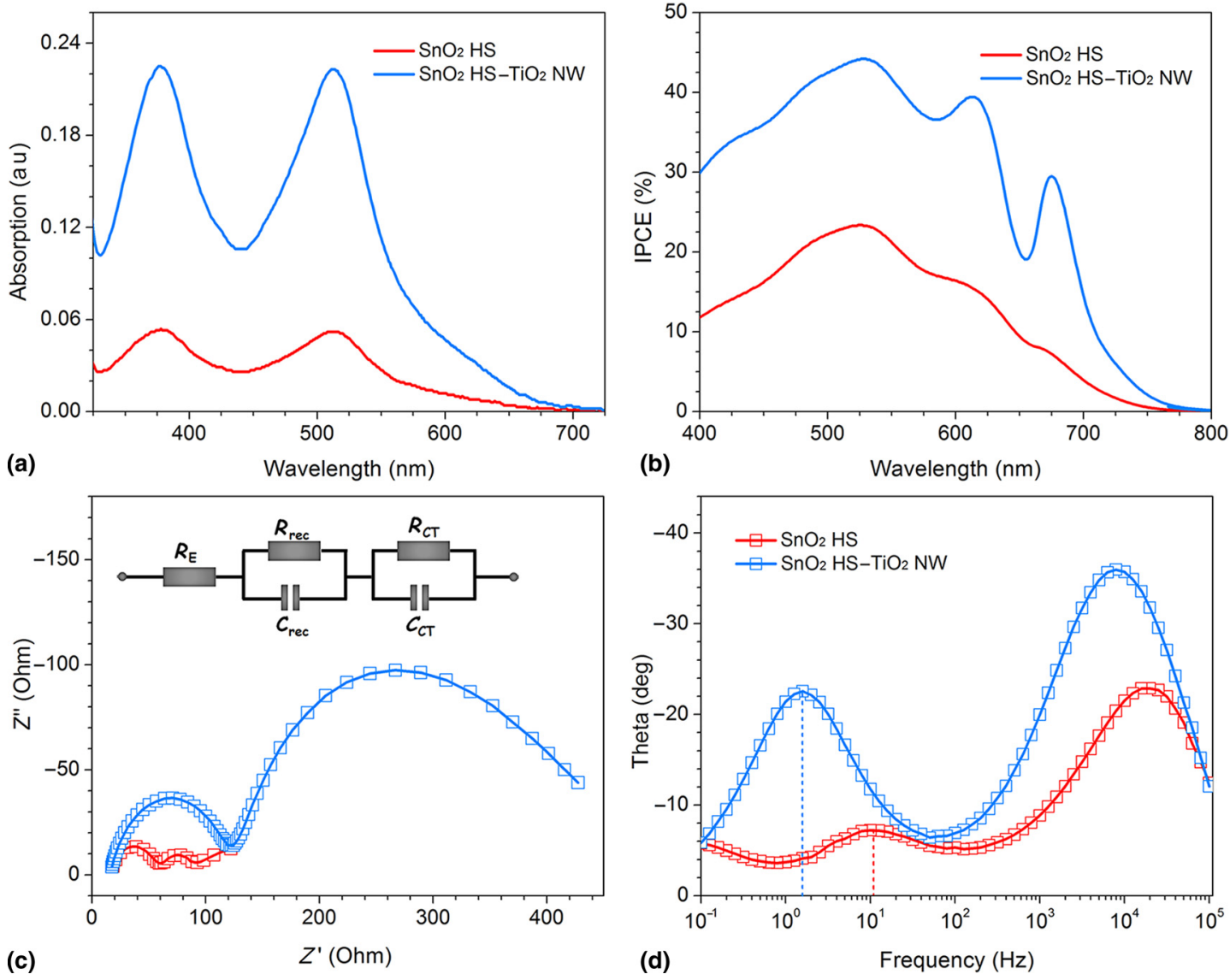

Figure 4. (a) The comparison of UV-vis absorption spectra of dyes dissolved in ethanol, unloaded from respective $\mathrm{SnO}_{2} \mathrm{HS}_{\text {and }} \mathrm{SnO}_{2} \mathrm{HS}-\mathrm{TiO}_{2} \mathrm{NW}$ photoanodes; (b) IPCE spectra of DSCs with the two photoanodes; (c) the Nyquist plots; and (d) Bode curves of electrochemical impedance $\mathrm{spectra}$ of $\mathrm{SnO}_{2} \mathrm{HS}$ and $\mathrm{SnO}_{2} \mathrm{HS}-\mathrm{TiO}_{2} \mathrm{NW}$ photoanodes with a forward bias of open-circuit voltage, the inset is an equivalent circuit of the solar cells.

adsorbed nitrogen volume at relative pressures ranging from 0.05 to 0.65 , and suggested a possible capillary force-induced shrinkage and/or partial collapse of the porous structure. So the pore volume and possibly the BET surface area measured here with nitrogen sorption isotherms are most likely much smaller than the real values. $\mathrm{TiO}_{2} \mathrm{NWs}$ grown on the surface of $\mathrm{SnO}_{2} \mathrm{HSs}$ and filling the space between spheres would contribute to the increased BET surface area with reduced pore size and porosity. Figure 3(c) shows two films' light-scatting ability measured by the UV-vis diffuse reflectance spectroscopy, and reveals that the diffuse reflection of $\mathrm{SnO}_{2} \mathrm{HS}$ film is much higher than the $\mathrm{SnO}_{2} \mathrm{HS}-\mathrm{TiO}_{2} \mathrm{NW}$ film. Here are three possible reasons about two films with different diffuse reflection: (1) the growth of $\mathrm{TiO}_{2} \mathrm{NWs}$ on the surface of $\mathrm{SnO}_{2} \mathrm{HS}$ layer would definitely increase the surface roughness, and thus reduce the light-scatting ability of the $\mathrm{SnO}_{2} \mathrm{HS}-\mathrm{TiO}_{2} \mathrm{NW}$ film. (2) The $\mathrm{SnO}_{2} \quad \mathrm{HS}-\mathrm{TiO}_{2} \mathrm{NW}$ film would definitely have a lower packing density, which would contribute to a reduced diffuse reflection. (3) Although $\mathrm{TiO}_{2}$ possesses the index of refraction of 2.488, appreciably higher than that of $\mathrm{SnO}_{2}$, $2.006,{ }^{[34]}$ the amount of $\mathrm{TiO}_{2}$ might be too small to make significant impact.
BET surface area differences between the sample $\mathrm{SnO}_{2} \mathrm{HS}$ and $\mathrm{SnO}_{2} \mathrm{HS}-\mathrm{TiO}_{2} \mathrm{NW}$ also affect the amount of dye adsorption, and then have an impact on the performance of DSCs based on two different photoanodes. Figure 4(a) shows the curves of dye absorption and details summarized in Table I. Owing to the poor adsorption property of $\mathrm{SnO}_{2}$ HS photoanode with dye molecules, it provides very low dye loading of $2.12 \times$ $10^{-8} \mathrm{~mol} / \mathrm{cm}^{2}$. By contrast, $\mathrm{TiO}_{2}$ have a good associativity with dye molecules and the loose structure because of the NWs existing and the value of dye loading in $\mathrm{SnO}_{2} \mathrm{HS}-\mathrm{TiO}_{2}$ NW photoanode is $7.64 \times 10^{-8} \mathrm{~mol} / \mathrm{cm}^{2}$, more than three times of the amount of dye loaded on $\mathrm{SnO}_{2}$ HS photoanode. The ameliorative dye loading can obviously improve the light harvesting, possibly resulting in the enhanced photocurrent density and subsequently the power conversion efficiency of the solar cells if other properties are kept the same. According to the BET surface area data, $\mathrm{SnO}_{2} \mathrm{HS}-\mathrm{TiO}_{2} \mathrm{NW}$ sample has the specific surface area, 1.8 times larger than that of $\mathrm{SnO}_{2}$ HS sample, whereas 3.6 times more dye loading than $\mathrm{SnO}_{2} \mathrm{HS}$. The possible explanation for such differences in BET surface areas and in dye-loading data is ascribed to the different dye-loading ability of metal oxides stemming 
Table I. Parameters of the BET testing results, impedance measurements and the amount of dye loaded in $\mathrm{SnO}_{2} \mathrm{HS}$ and $\mathrm{SnO}_{2} \mathrm{HS}-\mathrm{TiO}_{2} \mathrm{NW}$ photoanodes.

\begin{tabular}{llllccc}
\hline DSCs & Surface area $\left(\mathrm{m}^{2} / \mathrm{g}\right)$ & Pore volume $\left(\mathrm{cm}^{3} / \mathrm{g}\right)$ & Dye loading $\left(\times 10^{-8} \mathrm{~mol}^{\left.-\mathrm{cm}^{2}\right)}\right.$ & $\tau_{\mathrm{r}}(\mathrm{ms})$ & $R_{\text {rec }}(\Omega)$ & $R_{\mathrm{ct}}(\Omega)$ \\
\hline $\mathrm{SnO}_{2} \mathrm{HS}$ & 21 & 0.15 & 2.12 & 15.9 & 33 & 43 \\
\hline $\mathrm{SnO}_{2} \mathrm{HS}_{-}-\mathrm{TiO}_{2} \mathrm{NW}$ & 39 & 0.09 & 7.64 & 100.5 & 203 & 107 \\
\hline
\end{tabular}

from their different surface chemistry and surface energy, $\mathrm{SnO}_{2}$ has less dye adsorption owing to its lower isoelectric point (i.e. p., at $\mathrm{pH} 4-5)$, while $\mathrm{TiO}_{2}$ has higher isoelectric point (i.e.p., at $\mathrm{pH}$ 6-7). ${ }^{[21]}$

To further understand the photovoltaic properties of DSCs with the photoanode of $\mathrm{SnO}_{2} \mathrm{HS}$ and $\mathrm{SnO}_{2} \mathrm{HS}-\mathrm{TiO}_{2} \mathrm{NW}$, the IPCEs were characterized with the results shown in Fig. 4 (b). The IPCE is defined as the number of electrons detected in the external circuit produced by an incident photon at a given wavelength, related to electron injection efficiency, dye regeneration efficiency, charge collection efficiency, and lightharvesting efficiency. ${ }^{[35]}$ The IPCE values of the solar cell constructed with $\mathrm{SnO}_{2} \mathrm{HS}-\mathrm{TiO}_{2} \mathrm{NW}$ powder of about $45 \%$ are much higher than that of the device based on $\mathrm{SnO}_{2} \mathrm{HS}$ powder, of $<25 \%$. This figure clearly showed that the solar cells based on $\mathrm{SnO}_{2} \mathrm{HS}-\mathrm{TiO}_{2} \mathrm{NW}$ electrode has better performances, attributing to better dye loading and light scattering in the whole wavelength region from 400 to $750 \mathrm{~nm}$. It is noted that two photoanodes both have HS structures, which have a good impact on light-scattering properties in longer wavelength regions. $^{[35]}$

The EIS measurements are carried out in the frequency range from $0.1 \mathrm{~Hz}$ to $100 \mathrm{kHz}$ so as to study the interfacial charge transfer process in the DSCs based on $\mathrm{SnO}_{2} \mathrm{HS}$ and $\mathrm{SnO}_{2} \mathrm{HS}-\mathrm{TiO}_{2} \mathrm{NW}$ photoanodes. As shown in Fig. 4(c), the Nyquist plots of the two photoanodes are measured at a forward

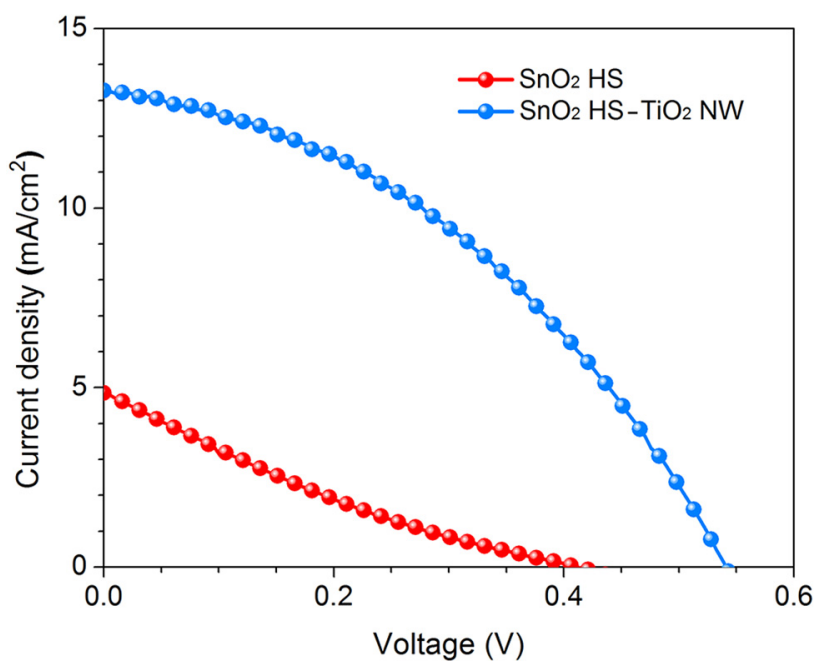

Figure 5. The $J-V$ curves of the DSCs with $\mathrm{SnO}_{2} \mathrm{HS}$ and $\mathrm{SnO}_{2} \mathrm{HS}-\mathrm{TiO}_{2} \mathrm{NW}$ photoanodes of a thickness of $20 \mu \mathrm{m}$ and sensitized with N719. bias of the open-circuit voltage under $100 \mathrm{~mW} / \mathrm{cm}^{2}$ and the equivalent circuit is presented as an inset. In general, the first semicircle occurring at high frequencies in the Nyquist plots presents the parallel connection of charge-transfer resistance $\left(R_{\mathrm{ct}}\right)$ and the interfacial capacitance $\left(C_{\mathrm{c}}\right)$ at the counter electrode/electrolyte interface, while the second semicircle at lowfrequency region is the charge recombination resistance $\left(R_{\text {rec }}\right)$ occurring at the metal oxide/dye/electrolyte interface and the chemical capacitance that stands for the change of electron density $\left(C_{\text {rec }}\right)$. The charge transfer resistance of $\mathrm{SnO}_{2} \mathrm{HS}_{-} \mathrm{TiO}_{2}$ $\mathrm{NW}$ is larger than that of $\mathrm{SnO}_{2} \mathrm{HS}$, which probably means that the poor electron mobility of $\mathrm{TiO}_{2}$ results in slower electron transfer process between the counter electrode and electrolyte interface. Since the hydrothermal grown $\mathrm{TiO}_{2}$ not only increased the specific surface area of the nanostructured material, but also passivated the surface defects of $\mathrm{SnO}_{2}$ photoanode, the surface recombination routes are blocked, leading to a dramatic increase on the charge recombination resistance of $\mathrm{SnO}_{2} \mathrm{HS}-$ $\mathrm{TiO}_{2}$ NW photoanode. The values of $R_{\text {rec }}, R_{\mathrm{ct}}$, and calculated electron lifetime $\left(\tau_{\mathrm{r}}\right)$ corresponding to $\mathrm{SnO}_{2} \mathrm{HS}$ and $\mathrm{SnO}_{2}$ HS- $\mathrm{TiO}_{2} \mathrm{NW}$ are also listed in Table I. The $\tau_{\mathrm{r}}$ can be calculated from the expression: $\tau_{\mathrm{r}}=1 / 2 \pi f_{\mathrm{r}}$, where $f_{\mathrm{r}}$ is the characteristic frequency minimum of Bode figure [see Fig. 4(d)]. The calculated electron lifetime in $\mathrm{SnO}_{2} \mathrm{HS}-\mathrm{TiO}_{2} \mathrm{NW}$ electrode is $100.5 \mathrm{~ms}$, much longer than that in $\mathrm{SnO}_{2}$ HS film with $15.9 \mathrm{~ms}$, which suggests less charge recombination in $\mathrm{SnO}_{2} \mathrm{HS}-\mathrm{TiO}_{2} \mathrm{NW}$ photoanodes owing to coating of $\mathrm{TiO}_{2}$ on the surface of $\mathrm{SnO}_{2} \mathrm{HS}$ as well as the growth of $\mathrm{TiO}_{2} \mathrm{NWs}$.

Figure 5 shows the $J-V$ curves of DSC devices with photoanodes made of $\mathrm{SnO}_{2} \mathrm{HS}$ and $\mathrm{SnO}_{2} \mathrm{HS}-\mathrm{TiO}_{2} \mathrm{NW}$, respectively. Detailed parameters are listed in Table II. The highest power conversion efficiency of DSC based on $\mathrm{SnO}_{2} \mathrm{HS}-\mathrm{TiO}_{2} \mathrm{NW}$ can reach $2.9 \%$, while the only $0.4 \%$ was achieved in the DSC based on $\mathrm{SnO}_{2}$ HS photoanode. On account of larger BET surface area with significantly more dye loading with good light-scatting ability, the short-circuit photocurrent density of $\mathrm{SnO}_{2} \mathrm{HS}-\mathrm{TiO}_{2} \mathrm{NW}$ is much higher than that of $\mathrm{SnO}_{2} \mathrm{HS}$.

Table II. Comparison of short-circuit current density $\left(J_{\mathrm{Sc}}\right)$, open-circuit voltage $\left(V_{\text {oc }}\right)$, fill factor $(\mathrm{FF})$, and power conversion efficiency $(\eta)$ of solar cells with $\mathrm{SnO}_{2} \mathrm{HS}$ and $\mathrm{SnO}_{2} \mathrm{HS}-\mathrm{TiO}_{2} \mathrm{NW}$ as photoanodes, respectively.

\begin{tabular}{lllll}
\hline $\mathrm{DSCs}$ & $J_{\mathrm{sc}}\left(\mathrm{mA} / \mathrm{cm}^{2}\right)$ & $V_{\mathrm{oc}}(\mathrm{V})$ & $\mathrm{FF}$ & $\eta(\%)$ \\
\hline $\mathrm{SnO}_{2} \mathrm{HS}-\mathrm{TiO}_{2} \mathrm{NW}$ & 13.3 & 0.54 & 0.40 & 2.9 \\
\hline $\mathrm{SnO}_{2} \mathrm{HS}$ & 4.9 & 0.41 & 0.20 & 0.4 \\
\hline
\end{tabular}


In addition, $\mathrm{TiO}_{2} \mathrm{NWs}$ and coating on the surface of $\mathrm{SnO}_{2} \mathrm{HS}$ effectively suppress the charge recombination result in noticeable improvement on the open-circuit voltage. Since fill factor is directly related to the charge recombination resistance and charge transfer resistance $\left(R_{\mathrm{rec}} / R_{\mathrm{ct}}\right)$, the surface modification with $\mathrm{TiO}_{2}$ coating or NWs appreciably enhanced the charge recombination resistance and consequently increased the fill factor.

\section{Conclusions}

$\mathrm{TiO}_{2} \mathrm{NW}$-modified $\mathrm{SnO}_{2} \mathrm{HSs}$ was prepared using a sequential template-free hydrothermal method for the first time, while pure and high crystallinity product were obtained. During the hydrothermal reaction process, the specific area of the photoanode was significantly increased by the formation of $\mathrm{TiO}_{2}$ NWs, while the surface defects of $\mathrm{SnO}_{2}$ was dramatically reduced by the interfacial passivation effect. Therefore, the dye loading and light harvesting of the composite photoanode were enhanced, while the charge recombination was successfully suppressed. Consequently, the power conversion efficiency of the solar cell based on such $\mathrm{TiO}_{2} \mathrm{NW}$-modified $\mathrm{SnO}_{2} \mathrm{HS}$ photoanode reached $2.9 \%$, which represented six time enhancement as compared with the DSCs with $\mathrm{SnO}_{2} \mathrm{HS}$ electrodes.

\section{Acknowledgments}

This work was supported by the "thousands talents" program for pioneer researcher and his innovation team, China. This work was also supported by the National Science Foundation of China (grant numbers 51374029 and 91433102), Program for New Century Excellent Talents in the University (grant number NCET-13-0668), Fundamental Research Funds for the Central Universities (grant number FRF-TP-14-008C1), and China Postdoctoral Science Foundation (grant number 2014M550675).

\section{References}

1. B. Oregan and M. Gratzel: A low-cost, high-efficiency solar-cell based on dye-sensitized colloidal $\mathrm{TiO}_{2}$ films. Nature 353, 737 (1991).

2. Y. Bai, Y.M. Cao, J. Zhang, M. Wang, R.Z. Li, P. Wang, S.M. Zakeeruddin, and M. Gratzel: High-performance dye-sensitized solar cells based on solvent-free electrolytes produced from eutectic melts. Nat. Mater. 7, 626 (2008).

3. P. Wang, S.M. Zakeeruddin, J.E. Moser, M.K. Nazeeruddin, T. Sekiguchi, and M. Gratzel: A stable quasi-solid-state dye-sensitized solar cell with an amphiphilic ruthenium sensitizer and polymer gel electrolyte. Nat. Mater. 2, 402 (2003).

4. K. Kakiage, Y. Aoyama, T. Yano, K. Oya, J. Fujisawab, and M. Hanaya: Highly-efficient dye-sensitized solar cells with collaborative sensitization by silyl-anchor and carboxy-anchor dyes. Chem. Commun. 51, 15894 (2015).

5. E. Hendry, M. Koeberg, B. O'Regan, and M. Bonn: Local field effects on electron transport in nanostructured $\mathrm{TiO}_{2}$ revealed by terahertz spectroscopy. Nano Lett. 6, 755 (2006).

6. K. Zhu, N.R. Neale, A. Miedaner, and A.J. Frank: Enhanced chargecollection efficiencies and light scattering in dye-sensitized solar cells using oriented $\mathrm{TiO}_{2}$ nanotubes arrays. Nano Lett. 7, 69 (2007).

7. D.H. Chen, F.Z. Huang, Y.B. Cheng, and R.A. Caruso: Mesoporous anatase $\mathrm{TiO}_{2}$ beads with high surface areas and controllable pore sizes: a superior candidate for high-performance dye-sensitized solar cells. Adv. Mater. 21, 2206 (2009).

8. F. Sauvage, D.H. Chen, P. Comte, F.Z. Huang, L.P. Heiniger, Y.B. Cheng, R.A. Caruso, and M. Graetzel: Dye-sensitized solar cells employing a single film of mesoporous $\mathrm{TiO}_{2}$ beads achieve power conversion efficiencies over 10\%. ACS Nano 4, 4420 (2010).

9. K.C. Huang, Y.C. Wang, R.X. Dong, W.C. Tsai, K.W. Tsai, C.C. Wang, Y. H. Chen, R. Vittal, J.J. Lin, and K.C. Ho: A high performance dyesensitized solar cell with a novel nanocomposite film of PtNP/MWCNT on the counter electrode. J. Mater. Chem. 20, 4067 (2010).

10.J. Tian and G. Cao: Control of nanostructures and interfaces of metal oxide semiconductors for quantum-dots-sensitized Solar cells. J. Phys. Chem. Lett. 6, 1859 (2015).

11. Q.F. Zhang, C.S. Dandeneau, X.Y. Zhou, and G.Z. Cao: Zn0 nanostructures for dye-sensitized solar cells. Adv. Mater. 21, 4087 (2009).

12. Q.F. Zhang and G.Z. Cao: Nanostructured photoelectrodes for dyesensitized solar cells. Nano Today 6, 91 (2011).

13. C. Fei, J. Tian, Y. Wang, X. Liu, L. Lv, Z. Zhao, and G. Cao: Improved charge generation and collection in dye-sensitized solar cells with modified photoanode surface. Nano Energy 10, 353 (2014).

14. Y. Wang, J. Tian, C. Fei, L. Lv, X. Liu, Z. Zhao, and G. Cao: Microwaveassisted synthesis of $\mathrm{SnO}_{2}$ nanosheets photoanodes for dye-sensitized solar cells. J. Phys. Chem. C 118, 25931 (2014).

15. A.N.M. Green, E. Palomares, S.A. Haque, J.M. Kroon, and J.R. Durrant: Charge transport versus recombination in dye-sensitized solar cells employing nanocrystalline $\mathrm{TiO}_{2}$ and $\mathrm{SnO}_{2}$ films. J. Phys. Chem. B 109, 12525 (2005).

16.X.X. Xu, J. Zhuang, and X. Wang: $\mathrm{SnO}_{2}$ quantum dots and quantum wires: controllable synthesis, self-assembled $2 \mathrm{D}$ architectures, and gassensing properties. J. Am. Chem. Soc. 130, 12527 (2008).

17. D.F. Zhang, L.D. Sun, J.L. Yin, and C.H. Yan: Low-temperature fabrication of highly crystalline $\mathrm{SnO}_{2}$ nanorods. Adv. Mater. 15, 1022 (2003).

18.Z.W. Pan, Z.R. Dai, and Z.L. Wang: Nanobelts of semiconducting oxides. Science 291, 1947 (2001).

19. J. Zhang, S. Li, P. Yang, W. Que, and W. Liu: Deposition of transparent $\mathrm{TiO}_{2}$ nanotubes-films via electrophoretic technique for photovoltaic applications. Sci. China Mater. 58, 785 (2015).

20. Y.L. Wang, X.C. Jiang, and Y.N. Xia: A solution-phase, precursor route to polycrystalline $\mathrm{SnO}_{2}$ nanowires that can be used for gas sensing under ambient conditions. J. Am. Chem. Soc. 125, 16176 (2003).

21. A. Kay and M. Gratzel: Dye-sensitized core-shell nanocrystals: improved efficiency of mesoporous tin oxide electrodes coated with a thin layer of an insulating oxide. Chem. Mater. 14, 2930 (2002).

22. S. Ito, Y. Makari, T. Kitamura, Y. Wada, and S. Yanagida: Fabrication and characterization of mesoporous $\mathrm{SnO}_{2} / \mathrm{ZnO}$-composite electrodes for efficient dye solar cells. J. Mater. Chem. 14, 385 (2004).

23. N.G. Park, M.G. Kang, K.M. Kim, K.S. Ryu, S.H. Chang, D.K. Kim, J. van de Lagemaat, K.D. Benkstein, and A.J. Frank: Morphological and photoelectrochemical characterization of core-shell nanoparticle films for dyesensitized solar cells: $\mathrm{Zn}-0$ type shell on $\mathrm{SnO}_{2}$ and $\mathrm{TiO}_{2}$ cores. Langmuir 20, 4246 (2004).

24. H.B. Wu, J.S. Chen, X.W. Lou, and H.H. Hng: Synthesis of $\mathrm{SnO}_{2}$ hierarchical structures assembled from nanosheets and their lithium storage properties. J. Phys. Chem. C 115, 24605 (2011).

25. M. Law, L.E. Greene, J.C. Johnson, R. Saykally, and P.D. Yang: Nanowire dye-sensitized solar cells. Nat. Mater. 4, 455 (2005).

26. Y. Ohsaki, N. Masaki, T. Kitamura, Y. Wada, T. Okamoto, T. Sekino, K. Niihara, and S. Yanagida: Dye-sensitized $\mathrm{TiO}_{2}$ nanotube solar cells: fabrication and electronic characterization. Phys. Chem. Chem. Phys. 7, 4157 (2005).

27.B. Tan and Y.Y. Wu: Dye-sensitized solar cells based on anatase $\mathrm{TiO}_{2}$ nanoparticle/nanowire composites. J. Phys. Chem. B 110, 15932 (2006).

28. J.T. Jiu, S. Isoda, F.M. Wang, and M. Adachi: Dye-sensitized solar cells based on a single-crystalline $\mathrm{TiO}_{2}$ nanorod film. J. Phys. Chem. B 110, 2087 (2006).

29. L. Zhao, J.G. Yu, J.J. Fan, P.C. Zhai, and S.M. Wang: Dye-sensitized solar cells based on ordered titanate nanotube films fabricated by electrophoretic deposition method. Electrochem. Commun. 11, 2052 (2009). 
30.X.T. Yin, W.X. Que, D. Fei, H.X. Xie, and Z.L. He: Effect of $\mathrm{TiO}_{2}$ shell layer prepared by wet-chemical method on the photovoltaic performance of ZnO nanowires arrays-based quantum dot sensitized solar cells. Electrochim. Acta 99, 204 (2013).

31. H. Wang, B. Li, J. Gao, M. Tang, H.B. Feng, J.H. Li, and L. Guo: $\mathrm{SnO}_{2}$ hollow nanospheres enclosed by single crystalline nanoparticles for highly efficient dye-sensitized solar cells. CrystEngComm 14, 5177 (2012).

32.W.Q. Wu, Y.F. Xu, H.S. Rao, H.L. Feng, C.Y. Su, and D.B. Kuang: Constructing 3D branched nanowire coated macroporous metal oxide electrodes with homogeneous or heterogeneous compositions for efficient solar cells. Angew. Chem. Int. Ed. Engl. 53, 4816 (2014).

33. W.Q. Wu, B.X. Lei, H.S. Rao, Y.F. Xu, Y.F. Wang, C.Y. Su, and D.B. Kuang: Hydrothermal fabrication of hierarchically anatase $\mathrm{TiO}_{2}$ nanowire arrays on FTO glass for dye-sensitized solar cells. Sci. Rep. 3 (2013).

34.P. Patnaik: Handbook of Inorganic Chemicals (McGraw-Hill, New York, 2003).

35.S.H. Ahn, D.J. Kim, W.S. Chi, and J.H. Kim: Hierarchical double-shell nanostructures of $\mathrm{TiO}_{2}$ nanosheets on $\mathrm{SnO}_{2}$ hollow spheres for highefficiency, solid-state, dye-sensitized solar cells. Adv. Funct. Mater. 24, 5037 (2014). 